\title{
Dimensions of the Spiritual Needs of Muslim Chronic Patients: A Qualitative Study
}

\author{
Alireza Irajpour ${ }^{1}$ \\ Isfahan University of Medical Sciences
}

Maryam Moghimian ${ }^{2 *}$

Najafabad Branch, Islamic Azad University

${ }^{1}$ Associate Professor, Social Determinants of Health Research Center, Critical Care Nursing Department, School of Nursing \& Midwifery, Isfahan University of Medical Sciences, Isfahan, IR Iran.

${ }^{2}$ Nursing \& midwifery Sciences Development Research Center, Najafabad Branch, Islamic Azad University, Najafabad, IR Iran.

${ }^{*}$ Corresponding Author: Maryam Moghimian, Nursing \& Midwifery Sciences Development Research Center, Najafabad Branch, Islamic Azad University, Najafabad, IR Iran Tel: +989131143254, Fax: +98-3142291112, E-mail: mmoghimian243@gmail.com

Acknowledgments: We thank the participants affiliated with medical centers at the IUMS and Non-Educational Medical Centers in Isfahan for their generous consent to take part in the present study and sharing their feelings in difficult situations. The authors appreciate the funding of the Vice Chancellery for Research at IUMS.

Competing interests: Authors declare no conflicts of interest.

Funding: This study conducted as a part of the Ph.D. thesis financed by vice chancellor for Research and Technology of Isfahan University of Medical Sciences, project number 395255.

\section{Abstract}

Spiritual care is helpful for chronic patients in tolerating symptoms and dealing with conflicts relating to their diagnoses. The purpose of this study was to explore dimensions of the spiritual needs of chronic Muslim patients.

This exploratory qualitative study was conducted in Isfahan, Iran, with a purposive sample of 25 participants, including patients, family caregivers, nurses, 
physicians, psychologists, social workers, and religious counselors. Data were collected via semi-structured interviews and analyzed through conventional content analysis.

Results fell into two main themes: The first theme was transcendental needs, with two subthemes of religious needs and epistemology needs. The second theme was pleasurable needs and consisted of two subthemes, psycho-spiritual needs and spiritual support needs.

Providing spiritual support helps patients handle the problems of illness. The themes of spirituality revealed in this study have possible implications for routine patient care interactions.

Keywords: Spiritual needs, chronic disease, Muslim, qualitative study, Iran

\section{Background}

Spirituality is an innate need among humans, idealizing harmonious relationships between notions of self, others, nature, and God in the search of purpose in life (Pehler\& Craft-Rosenberg, 2009). When one is worried or involved in a crisis, attention to spirituality increases (Ellershaw, 2011). It is the view of this research team that every crisis is a spiritual crisis. Illness, disability, and lifethreatening events are among the most important crises that inspire semantic challenges and seeking meaning (Swift, 2016).

Chronic illness is a primary cause of disability and death across the globe (World Health Organization, 2015); diseases such as heart disease, cancer, diabetes, and chronic lung disease, are collectively responsible for almost $70 \%$ of all deaths worldwide (World Health Organization, 2016). Chronically ill patients with disabilities face stressful and life-threatening experiences. These experiences have a spiritual nature (Jaarsma, Beattie, Ryder, 2009).

Islamic tenets view the pain and suffering associated with chronic or terminal illnesses as a divine test, and some believers may interpret the situation as an opportunity to give meaning to life and show creativity in managing oneself (Asadi-Lari, Goushegir, Madjd, \& Latifi, 2008). These patients, in the face of injury and illness, prioritize their lives and may ask themselves ideological questions, such as whether God exists, what meaning there is in life, future consequences of their diagnoses, and whether they have reliable, trustworthy supporters (Cobb, Puchalski, \& Rumbold, 2012). Spiritual responses to these questions can be a useful resource for care and treatment, and the health care team plays a major role in increasing life expectancy; this begins by facilitating care through cooperation with priests and chaplains, directly addressing the ambiguities of chronic illness, and by referring patients to their faith communities (Taylor, Lillis, Lynn, \& LeMone, 2016).

As part of holistic care, health care team members are required to acquire 
necessary skills to detect spiritual needs of patients (McSherry \& Ross, 2010). Spiritual distress can be identified by questions relating to how illness affects notions of life's meaning (Davison, 2010). Of course, the various spiritual needs depend on cultural, historical, and social backgrounds and their special religious values (Edwards, Pang, Shiu, \& Chan, 2010), and meeting the needs of patients may be possible through interprofessional collaborations of the health care team (Irajpour, Ghaljaei, \& Alavi, 2015).

The researchers are aware of several studies that have been done on the spiritual needs of patients (Büssing \& Koenig, 2010; Nixon \& Narayanasamy, 2010; Hodge \& Horvath, 2011); in Iran, most of these studies have been conducted on cancer patients (Hatamipour, Rassouli, Yaghmaie, Zendedel, \& Majd, 2015; Rahnama, Khoshknab, Maddah, \& Ahmadi, 2012), and, despite high mortality rates, surprisingly little research has been done to study other chronic disease patients' preferences in end-of-life and disability care. On the other hand, the diversity of cultural and religious conditions prevailing in different cities of Iran requires regional studies. This study was conducted in Isfahan, a strongly religious city; the term "religion" is more commonly used by residents than "spirituality" (Sadeghi, Hasanpour, Heidarzadeh, Alamolhoda, \& Waldman, 2016). Isfahan is comprised of a 99 percent Muslim majority and minority communities of Christians, Jews, and Zoroastrians. In Islam, spiritual spirituality is considered as a calming and adaptive factor (Qur'an/ Fath, verse 4). The most important parts of spiritual needs are related to understanding the meaning of human nature and a person's relationship with God; these are based on religious beliefs, and relevant participant beliefs include a belief in God and the Prophet Muhammad, an afterlife following death, and in the trustworthiness of religious leaders (Bonab, Miner, \& Proctor, 2013).

\section{Materials and Methods}

This paper presents some findings from a larger dissertation study. The larger study employed a sequential mixed methods design to develop a clinical guideline for spiritual care delivery to chronically ill patients. This study dealt with the spiritual need of Muslim chronic patients. The main study question was What are the spiritual needs of Muslim chronic patients from the perspectives of the individual, the family, and the healthcare team?

\section{Design and setting}

This is a qualitative, exploratory study, and was conducted in 2016; qualitative researchers interpreted events in terms of participants' viewpoints (Grove, Burns, \& Gray, 2014). The study settings consisted of clinics, nursing homes, 
patients' private homes, and hospital wards (including cardiology, endocrinology, cancer, and respiratory care wards) in four teaching and non-teaching hospitals in Isfahan, Iran.

In this study, sampling was performed purposefully with a maximum variation to recruit 25 participants, including patients, family caregivers, nurses, physicians, psychologists, social workers, and religious counselors. Inclusion criteria for patients were being a minimum age of 20 years old and afflicted with chronic health conditions (such as diabetes mellitus, cancer, and/or cardiovascular or pulmonary diseases with debilitating complications). Moreover, inclusion criteria for family caregivers were a minimum age of 20 years old and in companionship with patients during hospitalization. For the health care professionals, the only inclusion criterion was three years of work experience with the patient. Exclusion criteria for patients were either medical prohibitions against participation or their reluctance to continue collaborative research; exclusion criteria for family caregivers and health care professionals was reluctance to continue collaborative research.

Data was collected between May and November 2016 via semistructured interviews. All of the interviews were conducted by the first author (MM). Interviews began with an explanation of the study, and asking the following research questions:

- What do you think you need more in this situation?

- How has your condition affected your behavior, your thoughts, and your needs?

- How is your relationship with God and people?

- What makes you happy or sad?

Supplementary questions guided the interviews to the goals of the study, and the interviews were completed with suggestions, such as Please explain more and give an example if you can. One participant was interviewed twice and the others once. Interviews ranged in duration from forty to sixty minutes. All interviews were recorded using an MP3 recorder.

\section{Data Analysis}

The analysis was conducted using a conventional qualitative content analysis method based on Graneheim and Lundman. In this method, the categories and their names are obtained from data (Graneheim \& Lundman, 2004). Immediately after conducting each interview, the first author listened to the recordings twice and made a word-by-word transcript of it. The interview transcript was then divided into meaning units and the units were coded, compared with 
each other, and grouped into primary subthemes. After that, both authors independently read and compared subthemes and categorized them into main themes according to their similarities and differences. Finally, they compared their generated themes and developed a shared set of subthemes and themes. In qualitative studies, there are no criteria for determining sample size and sampling continues until data saturation in all categories (i.e., data became saturated when new data are no longer produced; Streubert \& Carpenter, 2010). In this study, data saturation occurred after 26 interviews with 25 participants, yet two more interviews were done with a patient and a nurse to ensure saturation. These two interviews yielded no new data.

In this study, Denzin and Lincoln's aspects of trustworthiness were used (Lincoln \& Guba, 1985). To ensure the credibility of the findings, interview transcripts, analysis units, and the extracted initial codes were given to some participants (two patients, one nurse, and one religious counselor), and their supplementary comments were received and necessary modifications made (member-check). The long-term presence and the open interaction of the researcher with the participants to obtain rich and profound information and investigate the data and extracted categories were among the factors that increased the credibility of the data. In order to achieve dependability, the results of our analyses were reviewed and confirmed by ten experts in the areas of spirituality, qualitative research, and chronic diseases; the experts were external to this study (peer-check). Transferability was ensured through sampling different age groups, educational levels, and fields of study. Two nurses and two physicians who were external to the study, but had similar experiences to study participants were invited to review and confirm the similarity of our findings to their own experiences. External audit was also performed by an experienced qualitative researcher.

\section{Ethical considerations}

The research proposal was approved by the university Ethics Committee for Research. Before each interview, the intended interviewee was asked to read and sign the study informed consent form. Oral consent was given by participants to record their speech. Interviews were anonymized using numerical codes. Participants were assured of their right to voluntarily withdraw from the study. Moreover, they were ensured that they would have access to psychological support if they experienced any negative consequence as a result of participation in the study. None of the the participants requested psychological support and no negative consequences were detected by the researchers. 


\section{Results}

There were 25 study participants, comprising 14 patients, 8 health care professionals, and 3 family caregivers. Two patient participants were single and twelve were married, and half of the 14 patient participants were male. Healthcare professionals had an average work experience of fifteen years. Seventeen interviews were conducted with patients and family caregivers and nine by healthcare professionals(With an healthcare professional, two interviews were conducted). Participants' profile is shown in Table 1.

In total, four subthemes were generated and grouped into the two main themes of Transcendental needs and Pleasurable Needs. Together with their subthemes, these main themes are explained as follows in Table 2.

\section{Transcendental needs}

Muslim chronic patients reported following religious advice and understanding the meaning of life and death. These patients prayed for their healing and sometimes experienced conflicts as their continued illness suggested their prayers were not accepted.

\section{1a. Religious Needs}

Muslim chronic patients beliefs and relationships with God were taken into account. Patients were confident that life and death originated from God's power and was outside their authority. Interviews reflected needs to observe religious customs and perform religious practices, and made references to religious values.

Several interviews describe patient bedside prayer and having caregivers pray. In regard to religious needs, one of the nurses stated:

"We had so many cases where a patient who perhaps had never said prayers and hadn't believed in prayer even, knew his illness related to the sins done before and now in this situation, was looking for a way to have a spiritual relationship."

\section{(Expert Participant1)}

Participants believed that the reference to religious values such as asking forgiveness to compensate for the past, benediction, and begging forgiveness from others would lead to a feeling of comfort and acceptance of death. In this regard, one of the patients said: 
Table 1. Participants' profile

\begin{tabular}{|c|c|c|c|c|c|c|c|}
\hline Participants & $\begin{array}{l}\text { Participant } \\
\text { Code }\end{array}$ & Characteristics & $\begin{array}{c}\text { Age } \\
\text { (Years) }\end{array}$ & Gender & $\begin{array}{l}\text { Degree of } \\
\text { Education }\end{array}$ & $\begin{array}{l}\text { Marital } \\
\text { Status }\end{array}$ & $\begin{array}{l}\text { Number } \\
\text { of inter- } \\
\text { views }\end{array}$ \\
\hline \multirow[t]{14}{*}{$\begin{array}{l}\text { Patient } \\
\text { participant }\end{array}$} & PP1 & $\begin{array}{l}\text { Diabetic with neuropa- } \\
\text { thy and retinopathy }\end{array}$ & 58 & Female & Uneducated & Married & 1 \\
\hline & PP2 & Respiratory failure & 35 & Female & B.A & Single & 1 \\
\hline & PP3 & Metastatic colon cancer & 69 & Male & Uneducated & Married & 1 \\
\hline & PP4 & $\begin{array}{l}\text { Diabetic nephropathy } \\
\text { and retinopathy }\end{array}$ & 48 & Female & M.A & Married & 1 \\
\hline & PP5 & Congestive heart failure & 22 & Male & Diploma & Single & 1 \\
\hline & PP6 & Metastatic lung cancer & 65 & Male & Diploma & Married & 1 \\
\hline & PP7 & Congestive heart failure & 45 & Female & Diploma & Married & 1 \\
\hline & PP8 & $\begin{array}{l}\text { Diabetes with diabetic } \\
\text { foot amputation }\end{array}$ & 68 & Male & Diploma & Married & 1 \\
\hline & PP9 & Congestive heart failure & 54 & Male & B.S.C. & Married & 1 \\
\hline & PP10 & Metastatic brest cancer & 28 & Female & M.A & Married & 1 \\
\hline & PP11 & Respiratory failure & 33 & Male & M.Sc. & Married & 1 \\
\hline & PP12 & $\begin{array}{l}\text { Uterine cancer and } \\
\text { depression }\end{array}$ & 30 & Female & B.A & Married & 1 \\
\hline & PP13 & Respiratory failure & 67 & Female & Uneducated & Married & 1 \\
\hline & PP14 & $\begin{array}{l}\text { Leukemia with bone } \\
\text { metastases }\end{array}$ & 42 & Male & B.A & Married & 1 \\
\hline \multirow[t]{3}{*}{$\begin{array}{l}\text { Caregiver } \\
\text { participant }\end{array}$} & CP1 & $\begin{array}{l}\text { Daughter of diabetic } \\
\text { patient suffering from } \\
\text { complications }\end{array}$ & 28 & Female & B.Sc. & Single & 1 \\
\hline & $\mathrm{CP} 2$ & $\begin{array}{l}\text { Spouse of a chronic } \\
\text { heart disease patient }\end{array}$ & 39 & Female & Diploma & Married & 1 \\
\hline & CP3 & $\begin{array}{l}\text { Sister of breast cancer } \\
\text { patient }\end{array}$ & 25 & Female & Ph.D. & Single & 1 \\
\hline \multirow[t]{8}{*}{$\begin{array}{l}\text { Expert } \\
\text { Participant }\end{array}$} & EP1 & $\begin{array}{l}\text { Nurse with } 28 \text { years } \\
\text { work experience }\end{array}$ & 50 & Male & M.Sc. & Married & 2 \\
\hline & EP2 & $\begin{array}{l}\text { Social worker with } 10 \\
\text { years work experience }\end{array}$ & 32 & Female & B.Sc. & Married & 1 \\
\hline & EP3 & $\begin{array}{l}\text { Doctor with } 18 \text { years } \\
\text { work experience }\end{array}$ & 53 & Male & Internist & Married & 1 \\
\hline & EP4 & $\begin{array}{l}\text { Religious counselor } \\
\text { with } 13 \text { years work } \\
\text { experience }\end{array}$ & 47 & Male & $\begin{array}{l}\text { Ph.D in } \\
\text { Islamic } \\
\text { Resource }\end{array}$ & Married & 1 \\
\hline & EP5 & $\begin{array}{l}\text { Religious counselor } \\
\text { with } 7 \text { years work expe- } \\
\text { rience }\end{array}$ & 35 & Male & $\begin{array}{l}\text { Ph.D. Islamic } \\
\text { Resource }\end{array}$ & Married & 1 \\
\hline & EP6 & $\begin{array}{l}\text { Doctor with } 20 \text { years } \\
\text { work experience }\end{array}$ & 50 & Male & Oncologist & Married & 1 \\
\hline & EP7 & $\begin{array}{l}\text { Nurse with } 13 \text { years } \\
\text { work experience }\end{array}$ & 42 & Female & $\begin{array}{l}\text { B.Sc in } \\
\text { Nursing }\end{array}$ & Married & 1 \\
\hline & EP8 & $\begin{array}{l}\text { Doctor with } 10 \text { years } \\
\text { work experience }\end{array}$ & 40 & Male & Psychiatrist & Married & 1 \\
\hline
\end{tabular}


Table 2: Main themes, subthemes, and primary categories extracted

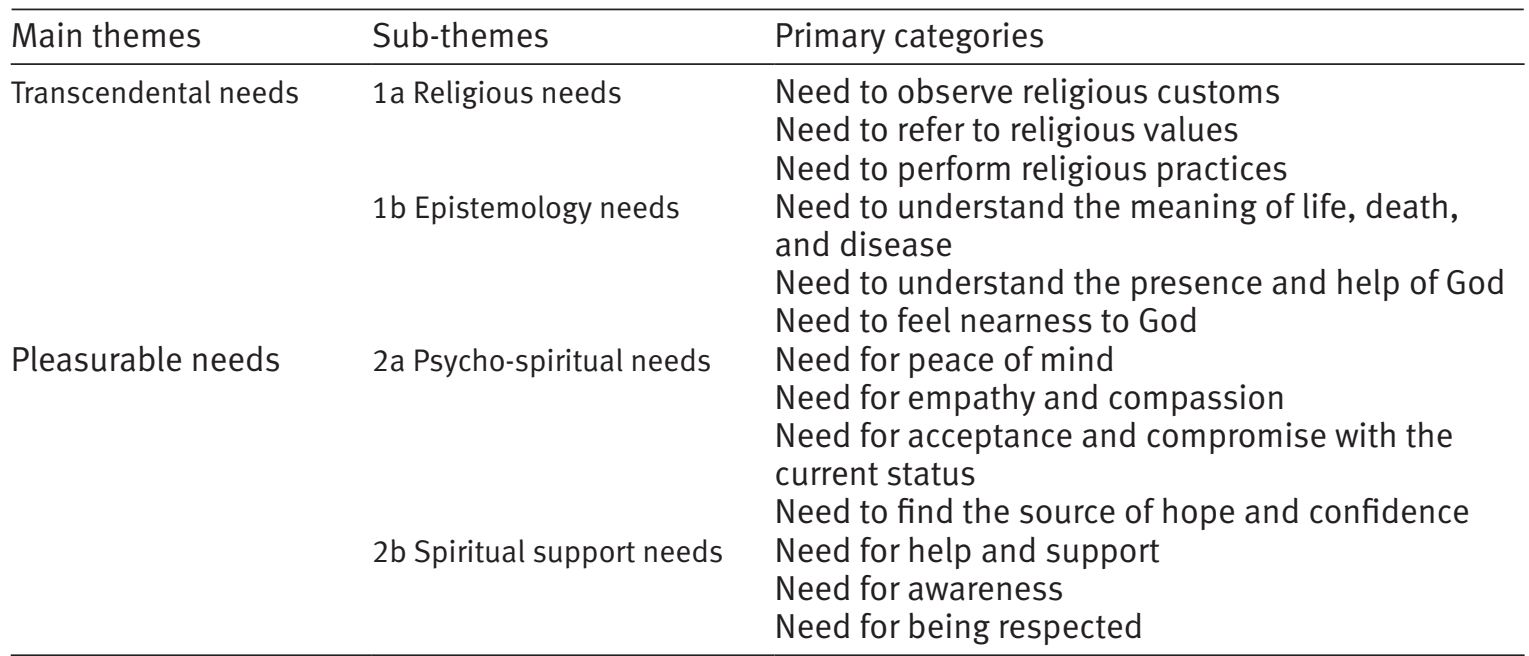

"I felt the song of departure. I had to make a plan. I have many unfinished works. But in my conditions, I must leave it to God. I repented. I asked for his forgiveness. My wings are open now and my heart has become clear to depart. I said goodbye to all and paid off all my debts." (Patient Participant 4)

One nurse stated that patients and their caregivers are willing to observe religious ceremonies and they feel happy when clinical care and treatment are done while saying religious words. One of the caregivers, the wife of the patient with heart failure, explained:

"My husband does not like to be hospitalized. He says, 'they don't let me get out of the bed and don't observe the cleanness when using a bedpan. I don't like to say my prayer in such conditions, I'm upset." (Caregiver Participant 2)

\section{1b. Epistemology needs}

Wanting nearness to God, the meaning of illness, life, and death, and understanding the presence and help of God were among the significant epistemology needs reported by patients. A patient with lung cancer said:

"That moment when my body becomes cold and my heart stops beating, it's as if God is calling me and says: Don't be afraid, I'm with you and will help you. You're coming to the place where I am." (Patient Participant 6) 
From the perspective of the healthcare team, the patient needs help to understand the meaning of death and immortality and meeting this need can be considered a source of hope for the continuation of life. In response to a question about patient spiritual needs based on their previous experiences, one doctor said:

"The most important need of such patients is to open a window into the world they are going to. If you did so for them, they have no more sorrow, their only sorrow is that now that I'm going to visit my Beloved God, I shouldn't be exhausted and when he understands that death is not the end of life, he wouldn't stop struggling and he would not feel disappointed til the last second." (Expert Participant 3)

Regarding cognitive needs, satisfactory responses to questions related to meaning and religious challenges are a priority. One chaplain participant visits patients at home and in the hospital and said this about his role in serving patients:

“The patient constantly thinks about the issue, that why God gave me this experience? Is God fair? Why that cruel person is not sick, but I am? They need someone to help them find the answers to such questions." (Expert Participant 5)

From the perspective of the participants, meeting religious and epistemology needs can help patients accept easy death and tolerate suffering and pain.

\section{Pleasurable Needs}

Pleasurable needs were formed by subthemes of psycho-spiritual and spiritual support needs.

\section{2a. Psycho-spiritual Needs}

Most patients expected their family and the heath care team to give them hope about their future healing. They tend to talk to the healthcare team in order to achieve comfort and expect their family to be with them and show them kindness and empathy, and expect this to restore their lost happiness. One of psychologists specified:

"I realized that we can only show empathy toward the person and listen to him; if we can help him if he has something to do and we can show him 
that he is not alone and his disease hasn't caused him to be rejected. This would seem to give satisfaction ..." (Expert Participant 8)

When asked about the need to have peace of mind, a patient with heart failure explained:

"I become low-spirited. They all are talking about me. Everyone wishes he/ she would not be like me. This condition is really bad. How much one can tolerate? I wish I had cancer instead I could breathe easier. I feel like crying. I wish there were someone who could understand what I say . . ." (Patient Participant 5)

\section{2b. Spiritual Support Needs}

The needs of help, support, respect, and awareness constituted spiritual support needs of patients and meeting such needs was deemed to lead to satisfaction and renewed spirit of patients.

A patient with respiratory failure said:

"When I feel sick, my children rush me to the hospital immediately. My wife all the way from home to hospital looks after me. In the hospital, nurses run to help too, as if God has given the nurses the power to give me a new life. They are so kind and respect me a lot so that I don't feel I'm in a hospital." (Patient Participant 2)

Due to multiple problems, these patients require different costly treatments. The insurance coverage, hospital support assistance, and charities play a major role in reducing financial stress that is imposed in addition to the suffering of illness and care on the families. In response to the question about the expectations of her patient, a caregiver of a diabetic patient explained:

"He fears if the medicine prescribed would not be covered by the insurance, so what should we do? We're very thankful to the charity which helps us. My husband grieves so much about our future. I cannot work, but we have trust and hope in God." (Caregiver Participant 1)

For patients, inner peace and happiness are the undeniable goals; to overcome the difficulties in achieving them is subjected to meeting patients' psycho-spiritual and spiritual support needs.

On the whole, dimensions of the spiritual need of Muslim patients with chronic diseases include religion, epistemology, psycho-spiritual, and spiritual 
support needs, categorized in two main themes of transcendental and pleasurable needs.

\section{Discussion}

One dimension of spiritual need is transcendental religious needs. The majority of patients and caregivers judged religion as an important factor in coping with the disease problems. The Qur'an also says that resorting to God is the basis of humans' peace and comfort (Qur'an/ Surah al-Imran, verse 139). Westerink and colleagues (2012) describe concepts of spirituality and religion overlapping with each other, each devoid of meaning if these concepts are separated (Westerink, 2012). In their study, Taleghani and colleague (2008) viewed prayer and resort effective in reducing the fear and anxiety of cancer patients and considering gaining support from God as a superior and source of hope, confidence, and security (Taleghani, Yekta, Nasrabadi, \& Käppeli, 2008). Their findings are consistent with the results of this study.

Epistemology needs was another dimension of transcendental needs. Spiritual practices, search for the meaning of life/death, and desire for immortality were among the needs discovered. These needs deepen when the patient, with his personal faith and understanding, evaluates the reasons of what is happening. Sacco and colleagues (2014) suggest that patients review life experiences in the stage of severe illness and interpret the meaning of their life accordingly (Sacco, Park, Suresh, \& Bliss, 2014). Loneliness and thinking in the meaning of life, creates a special spiritual condition in patients. They need help to overcome inner conflicts and to lose hope (Moghimian \& Salmani, 2010; Groleau, Whitley, Lespérance, \& Kirmayer, 2010). When patients get engaged in questions like What will happen in future?, the disease can turn into a tragedy that is a sign of psychosomatic symptoms (Taylor, Lillis, Lynn, \& LeMone, 2016). These findings confirm the results of our research.

Many hospitals in Isfahan, Iran, where this study was conducted, are served by a Religious counselor named Nasim Mehr, who helps patients faced with the challenges posed (Nasim Mehr Cultural \& Consultative Office, 2008). Interprofessional collaboration between the heath care team and Religious counselor is necessary to achieve the expected outcomes in spiritual care (Edwards, Pang, Shiu \& Chan, 2010; Irajpour, Ghaljaei, \& Alavi, 2015; Irajpour \& Alavi, 2015).

Pleasurable needs comprised another theme of spiritual needs. When patients were asked about their non-physical problems, part of their desires included maintaining communication with others, interest in family, hope, joyful opportunities, love and care of children, compassion of wife, and connections with friends and relatives. These issues revealed psycho- spiritual needs of pa- 
tients. Dev and colleagues (2013) stated that patients yearn for their family to be with them in the final stages of life (Dev et al., 2013). The health care team together with family and friends can help the patients achieve a pleasurable feeling of kindness and compassion (Paukert, Phillips, \& Cully, 2009).

Due to their changed role and diminished ability for being responsible and effective, patients needed spiritual support help to achieve comfort. For these patients, one dimension of care was related to physical affairs that they preferred to be done at home, and to have the health care team assist families in this process (Koszycki, Raab, Aldosary, \& Bradwejn, 2010). Support of charities and non-governmental associations, organizations, and insurance to cover the heavy expenses of chronic diseases accounted for a share of patients' needs. Studies have shown that supporting patients with incurable diseases financially can be one way to help the patient adapt to the diminished abilities status and the resulting crises (Agrimson \& Taft, 2009). The results of this study are consistent with other research, and health care teams should always remember that they need to assess patients' spiritual needs and consider special measures to meet these needs. This issue can include modification of the chronic patient's lifestyle in order to adapt to the process of treatment (Naghi, Philip, Phan, Cleenewerck, \& Schwarz, 2012).

One study limitation was that the study sample consisted of one small regional group of Iranian Muslims and results may not reflect the spiritual needs of others.

\section{Conclusion}

The results of this study and its comparison with other studies showed that Iranian Muslim chronic patients have spiritual needs integrated into their religion and culture, which may vary across the country, and Iranian health care providers should be involved in planning for holistic care based on the results of their regional studies. In this study, Muslim chronic patients who were referred to hospitals in Isfahan were sampled. This can limit the ability to generalize results to target populations of other cultures. Accordingly, this study can be repeated elsewhere under different cultural and religious conditions. Meanwhile, this study can be done with a variety of chronic patients not considered in this study, and further analyzed by evaluating gender, age, type of disease, stage of the disease, etc.

\section{References}

Agrimson, L. B., \& Taft, L. B. (2009). Spiritual crisis: A concept analysis. Journal of Advance Nursing, 65(2), 454-461. https://doi.org/10.1111/j.1365-2648.2008.04869.x 
Asadi-Lari, M., Goushegir, S., Madjd, Z., \& Latifi, N. (2008). Spiritual care at the end of life in the Islamic context, a systematic review. Iranian Journal of Cancer Prevention, 1(2), 63-67.

Bonab B. G., Miner, M., \& Proctor, M. T. (2013). Attachment to God in Islamic spirituality. Journal of Muslim Mental Health, 7(2), 77-104.

Büssing, A., \& Koenig, H. G. (2010). Spiritual needs of patients with chronic diseases. Religions, 1(1), 18-27. https://doi.org/10.3390/rel1010018

Cobb, M., Puchalski, C. M., \& Rumbold, B. (2012). Oxford textbook of spirituality in health care. Oxford: Oxford University Press. https://doi.org/10.1093/ med/9780199571390.001.0001

Davison, S. N. (2010). End-of-life care preferences and needs: Perceptions of patients with chronic kidney disease. Clinical Journal of the American Society of Nephrology, 5(2), 195-204. https://doi.org/10.2215/CJN.05960809

Dev, R., Coulson, L., Del, F. E., Palla, S .L., Yennurajalingam, S., Rhondali, W., et al. (2013). A prospective study of family conferences: Effects of patient presence on emotional expression and end-of-life discussions. Journal of Pain \& Symptom Management, 46(4), 536-545. https://doi.org/10.1016/j.jpainsymman.2012.10.280

Edwards, A., Pang, N., Shiu, V., \& Chan, C. (2010). The understanding of spirituality and the potential role of spiritual care in end-of-life and palliative care: A meta-study of qualitative research. Journal of Palliative Medicine, 24(8), 753-770. https://doi.org/10.1177/0269216310375860

Ellershaw, J. (2011). Care of the dying: A pathway to excellence. Oxford: Oxford University Press.

Graneheim, U. H., \& Lundman, B. (2004). Qualitative content analysis in nursing research: concepts, procedures and measures to achieve trustworthiness. Nursing Education Today, 24(2), 105-112. https://doi.org/10.1016/j.nedt.2003.10.001

Groleau, D., Whitley, R., Lespérance, F., \& Kirmayer, L. J. (2010). Spiritual reconfigurations of self after a myocardial infarction: Influence of culture and place. Health \& Place, 16(5), 853-860. https://doi.org/10.1016/j.healthplace.2010.04.010

Grove, S. K., Burns, N., \& Gray, J. R. (2014). Understanding Nursing Research: Building an Evidence-Based Practice, $6^{\text {th }}$ Ed. Philadelphia, PA: Elsevier Health Sciences.

Hatamipour, K., Rassouli, M., Yaghmaie, F., Zendedel, K., \& Majd, H. A. (2015). Spiritual needs of cancer patients: A qualitative study. 区Indian Journal of Palliative Care, 21(1), 61-.67. https://doi.org/10.4103/0973-1075.150190

Hodge, D. R., \& Horvath, V. E. (2011). Spiritual needs in health care settings: A qualitative meta-synthesis of clients' perspectives. Social work, 56(4), 306-316. https:// doi.org/10.1093/sw/56.4.306

Irajpour, A., \& Alavi, M. (2015). Health professionals' experiences and perceptions of challenges of inter-professional collaboration: Socio-cultural influences of IPC. Iranian Journal of Nursing \& Midwifery Research, 20(1), 99-104.

Irajpour, A., Ghaljaei, F., \& Alavi, M. (2015). Concept of collaboration from the Islamic perspective: The view points for health providers. Journal of Religion \& Health, 54(5), 1800-1809. https://doi.org/10.1007/s10943-014-9942-z

Jaarsma, T., Beattie, J. M., \& Ryder, M. (2009). Palliative care in heart failure: A position statement from the palliative care workshop of the Heart Failure Association of the European Society of Cardiology. Europian Journal of Heart Failure, 11(5), 433-443. https://doi.org/10.1093/eurjhf/hfp041

Koszycki, D., Raab, K., Aldosary, F., \& Bradwejn, J. (2010). A multi-faith spiritually based intervention for generalized anxiety disorder: A pilot randomized trial. Journal of Clinical Psychology, 66(4), 430-441. 
Lincoln, Y. S., \& Guba, E. G. (1985). Naturalistic Inquiry. Newbury Park, CA: Sage Publications.

McSherry, W., \& Ross, L. (2010). Spiritual assessment in health care practice. Uganda : M\&K Publishing

Moghimian, M., \& Salmani, F. (2010). The study of correlation between spiritual wellbeing and hope in cancer patients referring to Seyyedo Shohada Training-therapy Center of Isfahan University of Medical Sciences. Qom University of Medical Science Journal, 6(3), 40-45.

Naghi, J. J., Philip, K. J., Phan, A., Cleenewerck, L., \& Schwarz, E. R. (2012). The effects of spirituality and religion on outcomes in patients with chronic heart failure. Journal of Religion \& Health, 51(4), 1124-1136. https://doi.org/10.1007/s10943010-9419-7

Nasim Mehr Cultural \& Consultative Office (2008). Statutes of the offices of Nasim Mehr. Available at: http://www.nasime-mehr.ne.

Nixon, A., \& Narayanasamy, A. (2010). The spiritual needs of neuro-oncology patients from patients' perspective. Journal of Clinical Nursing, 19(15-16), 2259-2370. https://doi.org/10.1111/j.1365-2702.2009.03112.x

Paukert, A. L., Phillips, L., \& Cully, J. A. (2009). Integration of religion into cognitivebehavioral therapy for geriatric anxiety and depression. Journal of Psychiatric Practice, 15(2), 103-112. https://doi.org/10.1097/01.pra.0000348363.88676.4d

Pehler, S. R., \& Craft-Rosenberg, M. L. (2009). The lived experience of spirituality in adolescents with Duchenne muscular dystrophy. Journal of Pediatric Nursing, 24(6), 481-494. https://doi.org/10.1016/j.pedn.2008.06.008

Qur'an (2008). Translated by Ayatollah Makarem Shirazi. Tehran, IR: Publication center of Quran of Islamic Republic of Iran.

Rahnama, M., Khoshknab, M. F., Maddah, S. S., \& Ahmadi, F. (2012). Iranian cancer patients' perception of spirituality: A qualitative content analysis study. BMC Nursing, 11, 19-27. https://doi.org/10.1186/1472-6955-11-19

Sacco, S. J., Park, C. L., Suresh, D., \& Bliss, D. (2014). Living with heart failure: Psychosocial resources, meaning, gratitude, and well-being. Heart \& Lung, 43(3), 213218. https://doi.org/10.1016/j.hrtlng.2014.01.012

Sadeghi, N., Hasanpour, M., Heidarzadeh, M., Alamolhoda, A., \& Waldman, E. (2016). Spiritual needs of families with bereavement and loss of an infant in the neonatal intensive care unit: A qualitative study. Journal of Pain \& Symptom Management, 52(1), 35-42. https://doi.org/10.1016/j.jpainsymman.2015.12.344

Streubert, H. J., \& Carpenter, D. R. (2010). Qualitative research in nursing: Advancing the humanistic imperative ( $5^{\text {th }}$ ed.). Philadelphia, PA: Lippincott Williams and Wilkins.

Swift, C. (2016). Hospital chaplaincy in the twenty-first century: The crisis of spiritual care in the NHS. Aldershot, UK: Ashgate.

Taleghani, F., Yekta, Z. P., Nasrabadi, A. N., \& Käppeli, S. (2008). Adjustment process in Iranian women with breast cancer. Cancer Nursing, 31(3): E32-E41. https://doi. org/10.1097/01.NCC.0000305720.98518.35

Taylor, C. R., Lillis, C., Lynn, P. B., \& LeMone, P. (2016). Fundamentals of nursing: The art and science of person-centered nursing care ( $8^{\text {th }}$ ed.). Philadelphia, PA: University of Pennsylvania Press.

Westerink, H. (2012). Spirituality in psychology of religion: A concept in search of its meaning. International Journal of Psychology of Religion, 34 (1), 3-15. https://doi. org/10.1163/157361212X644486 
World Health Organization (2016). Noncommunicable diseases and their risk factors. Geneva: WHO. Available at: http://www.who.int/ncds/en/

World Health Organization (2015). The top 10 causes of death: The 10 leading causes of death by country income group . Available at: http://www.who.int/mediacentre/ Factsheets /fs310/en/index1.html 
